\title{
Scorpions (Arachnida, Scorpiones) at elevated altitudes of an area of conservation in the Caatinga
}

\author{
Phelipe Rêgo Lisboa de Souza'; Kátia Regina Benati "I; \\ Marcelo Cesar Lima Peres III
}

\begin{abstract}
This study aims to report the diversity of scorpions at elevated altitudes in the Parque Estadual das Sete Passagens (PESP), in an area of conservation located in the Chapada Diamantina within the Caatinga domain in north-eastern Brazil. Data collection occurred in December 2016 and December 2017, through the use of pitfall traps and nocturnal manual collection with the help of ultraviolet torches. 86 individuals were collected, pertaining to nine species, grouped into two families. The Bothriuridae represented $71 \%$ of samples, with Bothriurus sp. 1 occurring at all sample altitudes. Whereas, the Buthidae represente $29 \%$ of samples, with Ananteris sp, the most represented species, occurring at altitudes of 1,000m and 1,076m and Tityus stigmurus inhabiting areas with extensive human presence. The ample diversity found in the PESP, reveals that this location can be considered representative of the scorpiofauna of Bahia and of the Caatinga, especially due to the lack of data available on scorpions in semi-arid environments.
\end{abstract}

Keywords: Chapada Diamantina; Scorpiofauna; Parque Estadual das Sete Passagens

III Universidade Católica do Salvador, Salvador, Brazil. agendaperesmcl@gmail.com 


\section{INTRODUCTION}

Scorpions are chelicerate arthropods that occur in almost all terrestrial ecosystems (POLIS, 1990). They comprise a large order within the Arachnida class, with over 2,400 described species (REIN, 2019), distributed across 17 families (FET et al., 2000) and 163 catalogued genera (BRAZIL; PORTO, 2011).

Despite their occurrence in diverse terrestrial ecosystems, applying predatory pressure on other arthropods (BROWNELL; POLIS, 2001), the group is still poorly represented in many countries (SHEHAB et al., 2011; DI et al., 2013; BRAZIL; PORTO et al., 2011) and little is known about their diversity in semi-arid environments, especially in the Brazilian Caatinga (ARAÚJO et al., 2010; CARMO et al., 2013; PORTO et al., 2014).

The Caatinga is a semi-arid ecosystem known for its high temperatures and lack of water; it also represents one of the largest savannahs in the world, whose existence is restricted to Brazilian national territory (PRADO, 2003; LEAL et al., 2005). These peculiarities result in the formation of unique environments (SILVA, 2003; SILVA et al., 2017), whose areas can reach to altitudes of over 1,000m and present considerable levels of endemism ( BRASIL, 2005).

There are 28 species of scorpions in Caatinga, comprising 25\% of the endemism concerning Brazilian scorpiofauna (PORTO et al., 2014). Although it is one of the most representative ecosystems for scorpions, approximately 580 thousand $\mathrm{km}^{2}$ of the Caatinga has no register of species for this group, representing a very significant gap in data, especially since over $70 \%$ of its area is under-sampled (LIRA-DA-SILVA et al., 2005; PORTO et al., 2014; BARROS, 2018). This situation is directly evident through the absence of data related to the ecology and biology of species, registers of endemic elements, such as information on the occurrence and diversity of species found at elevated altitudes (LOURENÇO, 2010; PORTO et al., 2010; OTT; OTT, 2014; LIRA et al., 2019).

The current knowledge on scorpions at elevated altitudes in Brazil is basic, with a strong lack of data for the Caatinga and many ecosystems across national territory (LOURENÇO; EICKSTEDT, 2009; LOURENÇO, 1988; LIRA et al., 2016; OTT; OTT, 2014). 
Moreover, studies that have approached this subject are relatively recent, and have presented information in a secondary manner (BORTOLUZZI et al., 2007; BERTANI et al., 2008; LIRA; ALBUQUERQUE, 2014).

Thus, this study aimed to register scorpion species that occur in the Parque Estadual das Sete Passagens, investigating the distribution of species in environments with elevated altitudes.

\section{MATERIALS AND METHODS}

\subsection{Study area}

The study area was located in the Parque Estadual das Sete Passagens (PESP) $\left(11^{\circ} 22^{\prime} \mathrm{S}\right.$ e $\left.40^{\circ} 31^{\prime} \mathrm{W}\right)$, an area of conservation that stretches over 2,800 ha and is situated in the region of Chapada Diamantina, in the municipality of Miguel Calmon, Bahia.

Inserted in the Caatinga biome, the PESP has phytophysiognomies of seasonal forest and rocky plains and is located at an elevated altitude that varies between $800 \mathrm{~m}$ and 1,300m above sea level. The soil type is composed of Argisols and Neosols and is an area characterised by an average annual temperature of $23^{\circ} \mathrm{C}$, with precipitation levels of approximately 566mm (BAHIA, 2008).

The PESP is an area of conservation that was created in the year 2000 (State Law $n^{\circ} 7.808$ ), with the aim of protecting this space against illegal activities, the disappearance of endemic species and the exploration of water and gold resources. Although, two decades have almost passed since its creation, scientific research in this area is still recent.

Scorpions were collected with the permission of the Instituto Chico Mendes da Conservação de Biodiversidade (ICMBIO) \#52972-4, and of the Instituto do Meio Ambiente e Recursos Hídricos (INEMA) n 2016-007721/TEC/PES-0006. 


\subsection{Sample design}

Two sample collections were performed, both during the dry season. The first collection occurred in December 2016, and lasted two days, and the second collection occurred in December 2017, and lasted five days.

For the sampling of scorpiofauna, transects were placed at six elevated altitudes. The first elevated altitude was located at $920 \mathrm{~m}$ above sea level, the second at $1,000 \mathrm{~m}$, the third at $1,024 \mathrm{~m}$, the fourth at $1,049 \mathrm{~m}$, the fifth at $1,076 \mathrm{~m}$ and the sixth at $1,100 \mathrm{~m}$.

\subsection{Sampling}

For scorpion sampling, two collection methods were used: nocturnal manual collection and pitfall-traps.

The manual nocturnal collection was performed with the aid of ultraviolet torches at each altitude. At each altitude, four transects of $30 \mathrm{~m}$ were placed at intervals of $50 \mathrm{~m}$ between transects, placed at the same altitude. A pair of collectors walked along these transects for one hour, inspecting fallen trunks, burrows, bromeliads and other micro-environments, between 18:00-23:00. During the first collection, eight hours of sampling was performed and during the second collection 16 hours of sampling was performed, resulting in a total of 24 hours of sampling effort. A one-time occasional nocturnal manual collection occurred in an area designated for visitors to the PESP, an environment that did not fall within the environmental parameters established for the transects. Each individual was collected with the use of pincers and represented one sample. The captured animals were placed in plastic pots (universal collectors) with 70\% alcohol.

The pitfall-traps were comprised of plastic recipients (diameter of $20 \mathrm{~cm}$ and volume of 2 litres) buried at soil level. Liquid composed of hypersaline solution was placed in each recipient, to conserve the samples, as well as drops of detergent to reduce the superficial tension of the water. Two transects were implemented at a length of $100 \mathrm{~m}$ per altitude, with $50 \mathrm{~m}$ intervals between transects. For each transect, eight traps were installed, resulting in a total of 16 traps per altitude. These pitfall 
traps were placed at opposite sides of the transect i.e. four traps were placed on the right side of the transect and 4 on the left. The pitfall traps located on the same side were placed at intervals of $50 \mathrm{~m}$ and the traps on opposite sides were placed at $25 \mathrm{~m}$ intervals. In total, 80 traps were active for five consecutive days. These traps were only implemented during the second collection (December 2017) and were not used at the first elevated altitude $(920 \mathrm{~m})$.

Some of the collected material is available at the Zoological Collection at the Butantan Institute, São Paulo (Curator: Antônio Domingos Brescovit) and the rest can be found in the Arachnological Reference Collection of the Catholic University of Salvador, Bahia (Curator: Marcelo Cesar Lima Peres), Brazil.

\subsection{Data analysis}

The species richness estimate was based on the data provided by the joining of the registers collected using the two sampling methods, with the aim of obtaining information about the total number of species collected. Of the 13 estimators generated by the analysis, the Bootstrap Mean and Cole Rarefaction estimators were selected, due to the stability of their performances, as considering estimators that present curves with a greater tendency of stability and do not deviate from the observed species curve, is one of the best methods of interpreting the information obtained (TOTI et al., 2000).

Since the data for the species Tityus stigmurus were collected in environments out with the established sample design, they were not used in the estimated richness analysis.

\section{RESULTS}

Were collected 104 scorpions, belonging to nine species (Table 1). The most common species were Bothriurus sp1, which comprised $53.08 \%$ of the scorpions collected, followed by Anateris sp (19.85\%), Bothriurus asper Pocock, 1893 (4.40\%), 
Bothriurus sp.2 (7.40\%) and Anateris mauryi Lourenço 1982 (6.17\%). The species Tityus stigmurus (Thorell, 1876) was also collected during a one-time sampling event.

Table 1 - Frequency, sampling method and altitude of scorpions collected in the Parque Estadual das Sete Passagens

\begin{tabular}{|c|c|c|c|c|}
\hline Family & Species & $\begin{array}{c}\text { Number of } \\
\text { individuals (\%) }\end{array}$ & $\begin{array}{l}\text { Sampling } \\
\text { Method }\end{array}$ & Registered Altitude(s) \\
\hline \multirow{5}{*}{ Buthidae } & $\begin{array}{c}\text { Ananteris mauryi } \\
\text { Lourenço, } \\
1982\end{array}$ & $5(6.17 \%)$ & $\begin{array}{l}\text { Manual } \\
\text { nocturnal }\end{array}$ & $920 \mathrm{~m}$ and $1,049 \mathrm{~m}$ \\
\hline & Ananteris sp. & $16(19.85 \%)$ & $\begin{array}{c}\text { Manual } \\
\text { nocturnal / } \\
\text { Pitfall-traps }\end{array}$ & $\begin{array}{c}1,000,1,024,1,049 \text { and } 1,076 \\
m\end{array}$ \\
\hline & $\begin{array}{l}\text { Tityus } \\
\text { martinpaechi } \\
\text { Lourenço, } \\
1982\end{array}$ & $2(2.40 \%)$ & $\begin{array}{c}\text { Manual } \\
\text { nocturnal / } \\
\text { Pitfall-traps }\end{array}$ & 929 and $1,076 \mathrm{~m}$ \\
\hline & $\begin{array}{l}\text { Tityus neglectus } \\
\text { Mello-Leitão, } \\
1932\end{array}$ & $1(1.23 \%)$ & $\begin{array}{c}\text { Manual } \\
\text { nocturnal }\end{array}$ & $1,049 \mathrm{~m}$ \\
\hline & $\begin{array}{l}\text { Tityus stigmurus } \\
\text { (Thorell, 1876) }\end{array}$ & 23 & $\begin{array}{c}\text { Manual } \\
\text { nocturnal }\end{array}$ & - \\
\hline \multirow{4}{*}{ Bothriuridae } & $\begin{array}{r}\text { Bothriurus asper } \\
\quad \text { Pocock, } 1893\end{array}$ & $6(7.40 \%)$ & $\begin{array}{c}\text { Manual } \\
\text { nocturnal / } \\
\text { Pitfall-traps }\end{array}$ & $920,1,000$ and $1,100 \mathrm{~m}$ \\
\hline & $\begin{array}{c}\text { Bothriurus rochai } \\
\text { Mello-Leitão, } \\
1932\end{array}$ & $2(2.40 \%)$ & $\begin{array}{c}\text { Manual } \\
\text { nocturnal }\end{array}$ & $920,1,000$ and $1,076 \mathrm{~m}$ \\
\hline & Bothriurus sp.1 & $43(53.08 \%)$ & $\begin{array}{c}\text { Manual } \\
\text { nocturnal / } \\
\text { Pitfall-traps }\end{array}$ & $\begin{array}{c}1,000,1,024,1,049,1,076 \text { and } \\
1,100 \mathrm{~m}\end{array}$ \\
\hline & Bothriurus sp.2 & $6(7.40 \%)$ & $\begin{array}{c}\text { Manual } \\
\text { nocturnal / } \\
\text { Pitfall-traps }\end{array}$ & $1,000,1,049$ and $1,100 \mathrm{~m}$ \\
\hline
\end{tabular}

The area with an elevated altitude of $1,049 \mathrm{~m}$ above sea level was the most representative altitude, as the greatest number of individuals were found at this 
altitude (25), as well as the greatest number of species (5). Across the altitudinal gradient, the number of individuals from the Bothriuridae family represented more than double the number collected from the Buthidae family, with 57 and 24 individuals respectively.

From the Bothriuridae family, the species Bothriurus asper, B. rochai and Bothriurus sp.2 were collected at three altitudes, where together they represented $17 \%$ of the samples collected. Bothriurus sp.1 stood out, with the highest frequency of samples collected $(n=43)$, representing over half of the total number of scorpions collected. As well as being the most representative species, it also presented the greatest distribution between species observed in this study, occurring in five of six altitudes. Currently, this species is under description at the Butantan Institute, IBSP.

Within the Buthidae family, the species Ananteris mauryi and Tityus matinpaechi were observed at two altitudes, whereas, $T$. neglectus was found only at one altitude and where together the three species represented $10 \%$ of the samples collected. The Ananteris sp. occurred at four of the six altitudes and was the second most common species in this study, representing $20 \%$ of samples collected.

The species Tityus stigmurus was also collected in this study. However, all the individuals were observed to inhabit areas designated for tourists, that were located out-with the sample area established for this study. As such, the individuals collected were not included in the percentage of total species collected.

The majority of individuals of species Anateris sp. and Bothriurus asper were collected through manual nocturnal collection, which was also responsible for capturing all the individuals of the taxon A. mauryi and the only $T$. neglectus individual. On the other hand, the pitfall traps were responsible for collecting over half of the Bothriurus sp1. And Bothriurus sp. 2.

Joining together the data collected using the two sampling methods, generated estimates similar to the number of scorpion species collected in the PESP, where the accumulation curves aspired to stability. The Bootstrap Mean estimator presented better performance, estimating nine species, whereas, the Cole Rarefaction estimated eight species, demonstrating low variation between estimators (Figure 1). 
Figure 1 - The number of species observed (S(obs)) and richness observed of the scorpion species found from 24 samples in the Parque Estadual das Sete Passagens

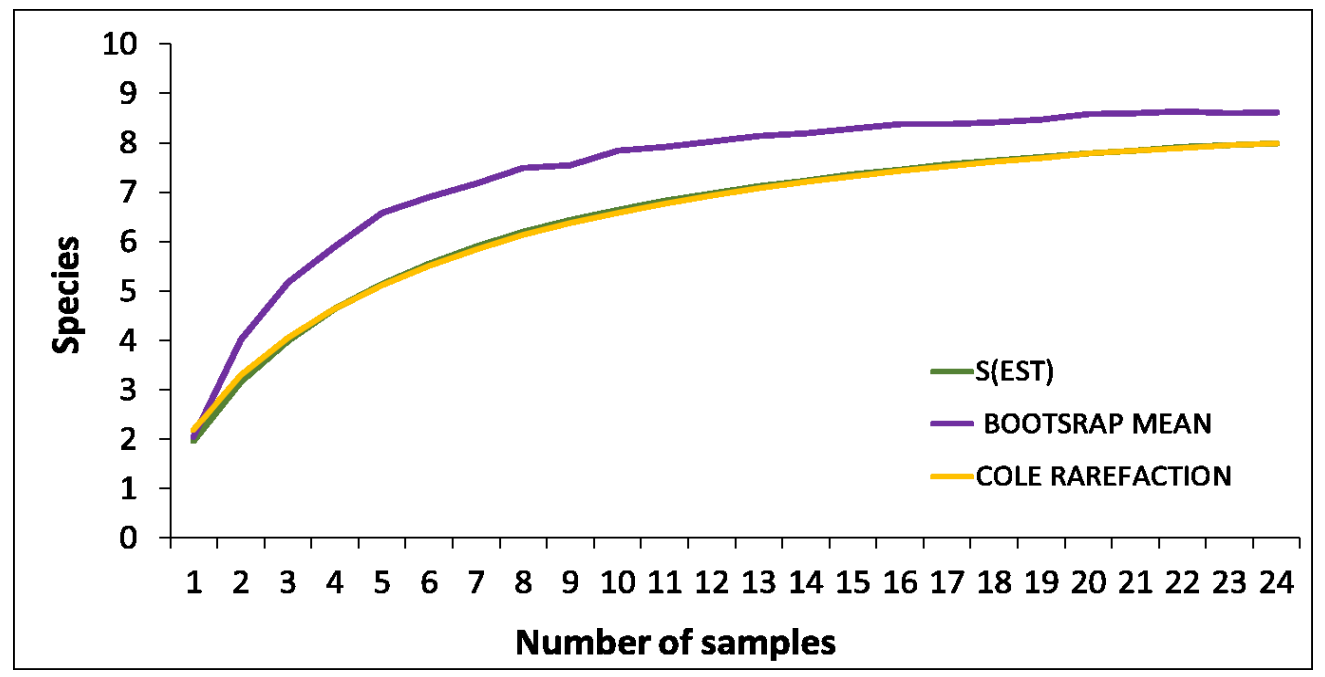

\section{DISCUSSION}

Bahia is a state in north-eastern Brazil which houses the largest diversity of scorpion species (28 species) in Brazil (BRAZIL; PORTO, 2011) and in terms of diversity, comes second only to the Brazilian state of Amazonas (PINTO-DA-ROCHA et al., 2007; CARVALHO et al., 2017). Despite this information, Porto et al. (2010) observed the existence of an extensive sampling gap, where there were no registers of scorpions in many natural and municipal areas, resulting in a total of over $60 \%$ of under-sampling across the entire state of Bahia.

The PESP was included in this percentage of under-sampling, as there were no scientific data on the scorpiofauna that occur in this area of conservation. However, this study demonstrated the occurrence of nine species, indicating that the study area can be considered scorpion-species rich.

This richness can be considered as ample when comparing the results to other areas, where studies have been performed with greater sample efforts, such as the Ferreira Penna and Juruti Plateua Scientific Station, Pará (6 sp.) (PINTO-DE-ROCHA et al., 2007), the Caxiuna National Florest, Pará (6 sp.) (BONALDO et al., 2009), the 
Marechal Newton Cavalcante Instruction Field, Pernambuco (5 sp.) (LIRA et al., 2018) and the Buraquinho Forest, Paraíba (4 sp.) (DIAS et al., 2006).

The occurrence of nine scorpion species in the PESP confirms the area as being an area of conservation, helping with the management of species, especially since serval locations considered as priority areas for the conservation of invertebrates in the Caatinga do not have registers of scorpions (PORTO et al., 2014). Furthermore, there are very few studies that register a representative and/or expressive number of scorpion species in this ecosystem (ARAÚJO et al., 2010; CARMO et al., 2013; LIRA et al., 2019) which is valuable for understanding the scorpiofauna of semi-arid ecosystems.

A reflection of this can be seen in a recent study in an area of Caatinga in northeastern Brazil. Carmo et al. (2013) required a sample effort of 216 hours to find six scorpion species. In another study carried out in a bioclimactic gradient between the Caatinga and Atlantic Forest, Lira et al. (2019) required 144 hours to find 10 scorpion species in the area of Caatinga alone. Whereas, with a sample effort of 144 hours, we registered eight species as well as one species registered during a one-time sampling event. As such, we required a lower sample effort and were still able to encounter an ample number of species.

The greatest number of individuals from the Bothriuridae family collected (70\% of the total) compared to those collected from the Buthidae family, is likely due to the different foraging habitats used by the two families, which may affect their relative abundances in the study area (ARAÚJO et al., 2010). The fossorial behaviour observed for taxa of the Bothriuridae family, favours the capture of individuals by pitfall traps (SCHMIDT, 2008; LIRA et al., 2018). However, the seasonality present in the Caatinga, appears to be predominant factor influencing scorpion foraging, in terms of searching for food resources, as well as searching for sexual partners (ARAÚjO et al., 2010; CARMO et al., 2013).

Despite their fossorial behaviour, Bothriurus asper and B. rochai were collected through manual nocturnal collection, between altitudes of $920 \mathrm{~m}$ and $1,076 \mathrm{~m}$. These species occur, principally, in the northeast of Brazil, with $B$. asper being restricted to 
this region (BRAZIL; PORTO, 2011; SANTOS-DA-SILVA et al., 2017). It is worth mentioning, that in the latest checklist referring to scorpiofauna in Bahia, Porto et al. (2010) did not list the occurrence of B. asper nor B. rochai in Miguel Calmon. As such, our observation of the two species in this municipality, extends their known distribution.

Bothriurus sp. 1, presented the greatest spatial distribution in this study, occurring in five of the six study altitudes, varying between altitudes of $1,000 \mathrm{~m}$ and $1,100 \mathrm{~m}$. Based on the results of this study, we can infer that this species presents less ecological requirements, especially due to its occurrence throughout almost the entire altitudinal gradient included in this study. Furthermore, 95\% of the individuals collected of this species were males, which may indicate a period of reproduction, with this being a key factor responsible for elevating Bothriuridae activity in the soil (ARAÚjO et al., 2010; OTT; OTT, 2014).

However, this species is currently being described at the Butantan Institute, IBSP and it is therefore, necessary to wait for the conclusion of this process to further explore discussions related to this species' habitat and reproductive preferences.

Ananteris sp. was the species with the second greatest special distribution in this study, occurring between altitudes of $1,000 \mathrm{~m}$ and $1,076 \mathrm{~m}$. This can be reflected through its active foraging habit, which has been previously described for other species related to this genus, such as Ananteris mauryi (LIRA et al., 2013; LIRA et al., 2018).As with Bothriurus sp. 1, this species is currently being described by the Butantan Institute, IBSP and as a result it is necessary to wait for the conclusion of this description in order to retrieve more information about its habits.

The Ananteris mauryi species was the fifth most common species collected in this study, occurring at altitudes of $920 \mathrm{~m}$ and $1,049 \mathrm{~m}$. This species frequently inhabits micro-environments of plant litter, especially in the Atlantic Forest, occurring in the superior or inferior layers, depending on the season and maturation phase (LIRA et al., 2013; SANTOS et al., 2018; DIONISIO-DA-SILVA, 2018). The first register of occurrence of this taxon in the state of Bahia occurred almost a decade ago (BRAZIL; PORTO, 2011; PORTO et al., 2010) however, this register did not include the 
municipality of Miguel Calmon and therefore, this study extends its distribution. Furthermore, its register in the Caatinga was based on data from scientific collections (PORTO et al., 2014). As such, in this study we confirm its occurrence in the Caatinga, however, this time through samples collected at elevated altitudes.

There is limited information on the species $T$. neglectus, which was collected at an altitude of $1,049 \mathrm{~m}$, due to the previous observation of a possible preference for the occupation of bromeliads (LOURENÇO; EICKSTEDT, 1988; LIRA; ALBUQUERQUE, 2014). This can be attributed to the preference and dependence that scorpions can present in determined micro-habitats (BROWNELL; POLIS, 2001). However, the only individual collected in this study occupied the superior region of plant litter and was not found near bromeliads (Pers. Obv).

Contrary to T. neglectus, there is no information on T. matinpaechi distribution, preference or any type of specification regarding analysed habitats, which is alarming, since as well as not being considered a species important to human health, it has been reported as being responsible for cases of scorpion stings in the state of Bahia (PORTO et al., 2010b). Additionally, its occurrence in Bahia, has been previously described for three other municipalities (Canarana, Central and Salvador) (PORTO et al., 2010), with it now being registered in the municipality of Miguel Calmon, extending its distribution.

Although it has not been previously collected through the use of transects established during sampling efforts, Tityus stigmurus was registered in this study. This species is considered to be synathropic and occurs in all regions across Brazil (LOURENÇO; EICKSTEDT, 2009; BRAZIL; PORTO, 2011). It is currently characterised as one of the most dangerous scorpions in the country, as it presents relative importance to public health (LIRA-DA-SILVA, 2000; RECKZIEGEL; PINTO, 2012), as well as being one of the most prevalent species in cases of scorpion stings in north-eastern Brazil and Bahai (LIRA-DA-SILVA, 2009; BATISTA et al., 2006; BRAZIL et al., 2009). The fact that we found several specimens over a short time frame in the PESP, reinforces the idea that new measures must be implemented to avoid accidents with this animal, 
especially since the individuals registered in this study were found to inhabit an environment with a significant human presence.

The differences observed in terms of the capture of species between altitudes can be related to the foraging behaviour of scorpions (ARAÚJO et al., 2010; LIRA et al., 2017). However, our data differed from those of Lira et al. (2013) for the species $A$. mauryi, which despite being an active forager and therefore, has the tendency of being observed in pitfall traps, was not collected by this method.

Furthermore, despite having been previously collected by pitfall traps (DIAS et al., 2006), the only $T$. neglectus individual was collected through active searching, a method that allowed for the sampling of this species, and that also aided in discussions about the ecological preferences of scorpions. This information reinforces the importance of the use of both methods, to allow for the most reliable sampling of scorpiofauna in an area, permitting the accumulation of new information and generating discussions on the topic of the ecology and biology of the species.

The date presented here demonstrate the occurrence of nine species of scorpions in the Parque Estadual das Sete Passagens, resulting in an increase in the distribution for some species and therefore, the location of the PESP becomes relevant for scorpiofauna in Bahia and the Caatinga. As such, this information demonstrates the importance of semi-arid environments for scorpions, through their unique ecological characteristics. This may encourage the production of new studies which evaluate the spatial distribution of these species, as well as studies investigating the biology of populations and research aiming to understand how species respond to physical and environmental variation at elevated altitudes in this ecosystem. However, it is still necessary to intensify the production of studies focussing on the Caatinga, especially because of the large quantity of environments that have still not been sampled and may potentially provide new information. 


\section{CONCLUSIONS}

The date presented here demonstrate the occurrence of nine species of scorpions in the Parque Estadual das Sete Passagens, resulting in an increase in the distribution for some species and therefore, the location of the PESP becomes relevant for scorpiofauna in Bahia and the Caatinga. As such, this information demonstrates the importance of semi-arid environments for scorpions, through their unique ecological characteristics. This may encourage the production of new studies which evaluate the spatial organisation of these species, as well as studies investigating the biology of populations and research aiming to understand how species respond to physical and environmental variation at elevated altitudes in this ecosystem. However, it is still necessary to intensify the production of studies focussing on the Caatinga, especially because of the large quantity of environments that have still not been sampled and may potentially provide new information.

\section{ACKNOWLEDGEMENTS}

We would like to thank the manager of the Parque das Sete Passagens, José Manoel Zélis Pereira, who permitted the collection of samples in the area and to all of the Forest Park Guards that provided fundamental support during the sampling. We would also like to thank the Catholic University of Salvador (UCSal) for their logistic support and CNPq, for the scientific initiation scholarship received by the first author. Our thanks extend to the students and collaborators of the Athropod Group in the Centre of Animal Ecology and Conservation (ECOA) that participated in the collection of samples. 


\section{REFERENCES}

ARAÚJO CS, CANDIDO DM, ARAÚJO HFP, DIAS SC, VASCONCELLOS A. Seasonal variations in scorpion activities (Arachnida: Scorpiones) in an area of Caatinga vegetation in northeastern Brazil. Rev. Bras. Zool. 2010; 27(3):372-376.

BARROS AMT. Uso de microhabitat e atividade de forrageio de escorpiões da Caatinga, em função da luminosidade lunar [monography]. Serra Talhada: Universidade Federal Rural de Pernambuco/UFRB;2018.

BATISTA CVF, ROMAN-GONZALEZ SA, SALAS-CASTILLO SP, ZAMUDIO FZ, GOMEZLAGUNAS F, POSSANI LD. Proteomic analysis of the venom from the scorpion Tityus stigmurus: biochemical and physiological comparison with other Tityus species. Comp. Biochem. Physiol. C-Toxicol. Pharmacol. 2007; 146:147-57.

BERTANI R, NAGAHAMA RK, ORTEGA DRM. Novos registros de Tityus brazilae Lourenço \& Eickstedt, 1984 (Scorpiones, Buthidae) para o Brasil, e observações sobre o habitat da espécie. Bol. Soc. Port. Entomol. 2008; 43:513-515.

BONALDO AB, CARVALHO LS, PINTO-DA-ROCHA R, TOURINHO AL, MIGLIO LT, CANDIANI DF et al. Inventário e História Natural dos Aracnídeos da Floresta Nacional de Caxiuanã, Pará, Brasil. 2009. Inventário e história natural dos aracnídeos da Floresta Nacional de Caxiuanã. In: LISBOA, P. L. B. org. Caxiuanã: desafios para a conservação de uma Floresta Nacional na Amazônia. Belém, Museu Paraense Emílio Goeldi. p. 577-621.

BORTOLUZZI LR, QUEROL MVM, QUEROL E. Notas sobre a ocorrência de Tityus serrulatus Lutz \& Mello, 1922 (Scorpiones, Buthidae) no oeste do Rio Grande do Sul, Brasil. Biota Neotrop. 2007; 7(3):357-359.

BRAZIL TK, LIRA-DA-SILVA RM, PORTO TJ, AMORIM AM, SILVA TF. Escorpiões de importância do estado da Bahia, Brasil. Gaz. Méd. Bahia. 2009; 79(1):38-42.

BRAZIL TK, PORTO TJ. Os Escorpiões. Salvador: EDUFBA;2011.

BROWNELL P, POLIS G. Scorpions biology and research. Oxford, University press; 2001.

CARMO RFR, AMORIM HP, VASCONCELOS SD. Scorpion diversity in two types of seasonally dry tropical forest in the semi-arid region of Northeastern Brazil. Biota Neotrop. 2013; 13(2):341-344.

CARVALHO LS, BRESCOVIT AD, SOUZA CAR, RAIZE J. Checklist dos escorpiões (Arachnida, Scorpiones) do Mato Grosso do Sul, Brasil. Iheringia, Sér. Zool. 2017; 107:1-7. 
DIAS SC, CANDIDO DM, BRESCOVIT AD. Scorpions from Mata do Buraquinho, João Pessoa, Paraíba, Brazil, with ecological notes on a population of Ananteris mauryi Lourenço (Scorpiones, Buthidae). Rev. Bras. Zool. 2006; 23(3):707-710.

DIONISIO-DA-SILVA W, LIRA AFA, ALBUQUERQUE CMR. Distinct edge effects and reproductive periods of sympatric litterdwelling scorpions (Arachnida: Scorpiones) in a Brazilian Atlantic forest. Zoology. 2018; 129,17-24.

DI ZY, YANG ZZ, YIN SJ, CAO ZJ, LI WX. History of study, updated checklist, distribution and key of Scorpions (Arachnida: Scorpiones) from china. Zool. Res. 2014; 35(1):3-19.

FET V, SISSOM SD, G LOWE, BRAUNWALDER ME. Catalog of the Scorpions of the World (1758-1998). New York, New York Entomological Society; 2002.

LEAL IR, SILVA JMC, TABARELLI M, LACHER JR TE. Changing the Course of Biodiversity Conservation in the Caatinga of Northeastern Brazil. Conserv. biol. 2005; 19(3):701706.

LIRA AFA, SOUZA AM, SILVA-FILHO AAC, ALBUQUERQUE CMR. Spatio-temporal microhabitat use by two co-occurring species of scorpions in Atlantic rainforest in Brazil. Zoology. 2013;116(3):182-185.

LIRA AFA, ALBUQUERQUE CMR. Diversity of scorpions (Chelicerata: Arachnida) in the Atlantic Forest in Pernambuco, northeastern Brazil. Check List. 2014; 10(6):1331-1335.

LIRA AFA, ARAUJO VLN, DE SOUZA AM, REGO FNAA, ALBUQUERQUE CMR. The effect of habitat fragmentation on the scorpion assemblage of a Brazilian Atlantic Forest. J. Insect. Conserv. 2016;20(3):457-466.

LIRA AFA, DAMASCENO EM, SILVA-FILHO AAC, ALBUQUERQUE CMR. Linking scorpion (Arachnida: Scorpiones) assemblage with fragment restoration in the Brazilian Atlantic Forest. Can. J. Zool. 2018; 96:963-972.

LIRA AFA, SALOMÃO RP, ALBUQUERQUE CMR. Pattern of scorpion diversity across a bioclimatic dry-wet gradient in Neotropical forests. Acta oecol. 2019; 96:10-17.

LIRA-DA-SILVA RM, AMORIM AM, CARVALHO FM, BRAZIL TK. Envenenamento por Tityus stigmurus (Scorpiones; Buthidae) no Estado da Bahia, Brasil. Ver. Soc. Bras. Med. Trop. 2000;33(3):239-245.

LIRA-DA-SILVA RM, JORDÃO GM, SILVA TF, CANDIDO DM, BRAZIL TK. Ocorrência de Rhopalurus debilis (C.L. Koch, 1840) (Scorpiones, Buthidae) no estado da Bahia, Brasil. Biota Neotrop. 2005;5(1):2-3.

LIRA-DA-SILVA RM, AMORIM AM, CARVALHO FM, BRAZIL TK. Acidentes por Escorpião na Cidade do Salvador, Bahia, Brasil (1982-2000). Gaz. Méd. Bahia. 2009;79(1):43-49. 
LOURENÇO WR, ELCKSTEDT VRD. Sinopse das espécies de Tityus do Nordeste do Brasil, com a redescrição da T. neglectus Mello-leitão (Scorpiones, Burthidae). Rev. bras. zool. 1988;5(3) 399-408.

LOURENÇO WR, EICKSTEDT VRDE. Escorpiões de Importância Médica. In: Cardoso JL, França FOS, Wen FH, Málaque CMS, Haddad Jr, editors. Animais Peçonhentos no Brasil: Biologia, Clínica e Terapêutica dos Acidentes. São Paulo: Sarvier; 2009. p.198213.

LOURENÇO WR. The disrupted pattern of distribution of the genus Hadrurochactas Pocock; evidence of past connections between Amazon and the Brazilian Atlantic forest. C. R. Biol. 2010; 333:41-47.

MINISTÉRIO DO MEIO AMBIENTE. Biodiversidade e Conservação da Chapada Diamantina. Brasília (Brasil): Ministério do Meio Ambiente, 2005. 411 p.

PINTO-DA-ROCHA R, ARAÚJO CO, BARREIROS JAP, BONALDO AB. Arthropoda, Arachnida, Scorpiones: Estação Científica Ferreira Penna and Juruti Plateau, Pará, Brazil. Check List. 2007; 3:145-147.

POLIS GA. The biology of Scorpions. Stanford: Stanford University Press; 1990.

PRADO DE. As Caatingas da América do Sul. In: Leal IR, Tabarelli M, SILVA JMC, editors. Ecologia e Conservação da Caatinga. Recife: Universidade Federal de Pernambuco; 2003. p. 3-74.

PORTO TJ, BRAZIL TK, LIRA-DA-SILVA RM. Scorpions, state of Bahia, northeastern Brazil. Check list. 2010;6(2): 292-297.

PORTO TJ, CALDAS EA, COVA BO, SANTOS VMN. Primeiro relato de acidentes escorpiônicos causados por Tityus martinpaechi Lourenço, 2001 (Scorpiones; Buthidae). Ver. Ciênc. Méd. Biol.2010b;9(3):266-269.

PORTO TJ, CARVALHO LS, SOUZA CAR, OLIVEIRA U, BRESCOVIT AD. Escorpiões da Caatinga: conhecimento atual e desafios. In: BRAVO F, CALOR A. Artrópodes do semiárido: Biodiversidade e Conservação do Semiárido. Feira de Santana: Printmídia; 2014. p.33-46.

OTT R, OTT AP. Abundância e sazonalidade de Bothriurus signatus (Arachnida, Scorpiones) em diferentes formações vegetais em São Francisco de Paula, RS, Brasil. Iheringia, Sér. Zool. 2014,104(1):92-98.

RECKZIEGEL GC, PINTO JR VL. Scorpionism in Brazil in the years 2000 to 2012. J. venom. Anim. Toxins incl. Trop. Dis. 2014; 20:46. 
REIN JO. The Scorpion Files-2019-Main page [Internet]. Trondheim: Norwegian University of Science and Technology; 2019 Out 2019 [Cited 2019 May 15]. Available from: http:// www.ntnu.no/ub/scorpion-files.

SANTOS-DA-SILVA AP, CARVALHO LS, BRESCOVIT AD. Two new species of Bothriurus Peters, 1861 (Scorpiones, Bothriuridae) from Northeastern Brazil. Zootaxa. 2017;4258(3):238-256.

SANTOS GCSG, DIONISIO-DA-SILVA W, SOUZA-ALVES JP, ALBUQUERQUE CMR, LIRA AFA. Random or clumped: How litter dwelling scorpions are distributed in a fragment of Brazilian Atlantic forest. Eur. J. Entomol. 2018; 115:445-449.

SCHMIDT GO. Levantamento dos escorpiões (Arachnida: Scorpiones) na Restinga da praia da Pinheira, Palhoça, Santa Catarina, Brasil. [monography]. Florianópolis: Universidade Federal de Santa Catarina Centro de Ciências Biológicas/CCB; 2008.

SECRETÁRIA DE MEIO AMBIENTE E RECURSOS HÍDRICOS, Governo da Bahia. Plano de Manejo do Parque Estadual das Sete Passagens vol.1. Salvador (Bahia): Governo da Bahia, 2008. 198 p.

SILVA JMC, TABARELLI M, FONSECA MT, LINS LV. Biodiversidade da Caatinga: áreas e ações prioritárias para a conservação. Brasília: UFPE; 2003.

SILVA JMC, LEAL IR, TABARELLI M. Caatinga: The Largest Tropical Dry Forest Region in South America. Switzerland: Springer; 2017.

SHEHAB AH, AMR ZS, LINDSELL JA. Ecology and biology of scorpions in Palmyra, Syria. Turk. J. Zool. 2011;35(3):333-341.

TOTI DS, COYLE FA, MILLER JA. A structured inventory of Appalachian grass bald and heath bald spider assemblages and a test of species richness estimator performance. J. Arachnol. 2000;28(3):329-345. 